\title{
特集「まちづくりにおける都市計画，建築規制の権限行使のあり方一 規制権者の裁量拡大論と規制基準明記論」にあたって The governmental standard for building and city planning regulation
}

Yu TOMITA

日本の現行の建築規制は容積率 $200 \%$, 建ぺい率 $60 \%$, 斜線制限 $1.25 / 1$ な゙の数值, 都市計画 図の色分けなどの色, 市街化区域と市街化調整区域を分ける線といった, 「数, 色, 線」による 明確な規制であることに特徴がある。この基準は, 数值で明確に規定できることから, 定量基準 と呼ぶことができる。

これに対し, 近年, 地方公共団体のまちづくり条例や景観法委任条例では, 例えば, 「周辺の 景観と調和した建築スケールとすること」,「通りや周辺との連続性を維持すること」,「外壁は周 辺の建物と調和した素材を用いること」,「海への眺望を阻害しないこと」といった言葉の基準に よる規制を行っている。

このような言葉の基準による規制は，定性基準，言語基準などと呼ばれるが本特集では，この 定性基準, 言語基準（以下，「定性基準」と呼ぶ。に）にる規制について，賛成する立場，改良を 前提に一部取り入れを容認する立場，反対する立場から，多方面にわたって議論していただいた。

座談会では，定性基準に賛成する立場から，全てを定量基準に書き込むことはできないこと， 仮に全てを事前明示的に定量基準として書き込もうとするとその社会的コストが膨大なものと なることを理由に定性基準の必要性が主張された。これに対し，定性基準に反対する立場からは， 定性基準の事前明示性の欠如から土地所有者に不測の財産権侵害を与えることへの懸念が示され， 全てを定量基準に明確に落とし込むことの必要性が主張された。定性基準の改良を前提にその一 部取り入れを容認する立場からは，定性基準をなるべく定量基準に転化させていく方向性及び定 性基準による規制を行うとしても土地所有者の権利を侵害しない形での規制とする方向性が主張 された。

富田論説「現行都市計画規制の失敗とその是正方策」では, 現行の定量基準による都市計画規 制において数多くの政府の失敗事例が生じている現実を紹介するとともに，これに定性基準に よって対応することの危険性, 定量基準再設定の必要性について考察している。

柳沢論説「裁量性基準の必要性と留意点」は, 現行の定量基準による規制はレディーメイド規 制であるがゆえに現実には過不足のある規制となっており，この過不足を解消するには多大な行 政コストがかかること, 現行の規制は基準に適合しさえすれば後は自由に建てられることから数 多くのトラブルが発生していることを指摘し, 定性基準の必要を説くとともに, 定性基準を採用 した場合の留意点を述べている。

野口論説「言語基準と実効性」は, 神奈川県真鶴町において協議調整手続を背景とした定性基 準によるまちづくりが行われていることを紹介するとともに, 現行の都市計画法を定性基準, 言 語基準に照らして審査する建築許可制度に改正することを提案している。

小浦論説「地域環境価值の評価を創出する開発調整のための基準とその運用」は, 兵庫県芦屋 市における景観法委任条例の運用を紹介し, 「周辺と調和する」という定性基準の意味は個別の 敷地により異なり，その内容は行政との協議調整の過程を経て明らかになることを述べる。そし 
て, 定量基準では敷地外の歴史や文化といった地域空間の特性を評価できないことを指摘すると ともに，敷地外の地域空間の特性を評価するための定性基準と協議調整の必要を述べている。

松本論説「分権思想に基づく『協議調整型まちづくり』と適正裁量」は, 地域特性を踏まえた 良好な地域空間価值の創出という観点から, 従来の中央主権的な事前確定ルールに代わって地方 公共団体と市民の連携による協議調整型のまちづくりが行われていること, 制度の運用に当たっ ては協議の標準処理期間の明示, 行政の恣意性の排除, 行政の専門性の補強等が必要であること を述べる。

角松論説「『協議調整型』まちづくりの制度設計とルール／スタンダード論」は，事前明示規 制をルール，事後的に規制内容が定まる規制をスタンダードと呼ぶとした場合，規制の適用頻度 が高い場合はルールによる規制が社会的に効率的であり，規制の適用頻度が非常に少ない場合は スタンダードによる規制が社会的に効率的であるとする。そのうえで, 特定の場所の景観の適否 といった規制の適用頻度が非常に低い場合には，ルールによる規制では非常に社会的コストが高 くなるためスタンダードによる規制が望ましく，定性基準はスタンダードによる規制として是認 されるとしている。ただし, 定性基準の予測可能性を高めることでこれをルールに近づけること も可能であるとしている。

黒木論説「裁量制度導入の設計実務への影響 設計者たちが考えそうなこと・期待したいこと」 は，裁量制導入の根拠として，(1)近隣紛争の予防，(2)より良い街並み形成があげられるが，(1)に ついては, 却って規制権者が紛争当事者双方から標的にされるリスク，(2)ついては，目標とす る地域空間の合意ができないリスクを指摘している。また，裁量権者の暴走によるリスクを指摘 するとともに，裁量制を導入したとしても現実にはマンパワー不足から実質的に意味のある審査 ができる場合は限られることを予測している。

安藤論説「建築規制における定量的基準と定性的基準」は, 建物による周辺環境悪化の適切な 評価と事前明示性の高い制度との間にはどちらかを実現しようとすると他方を実現することがで きないトレードオフの関係があることを指摘したうえで,「定性基準＋協議調整」によるまちづ くりでは, 必要以上の規制がなされ最有効利用が実現しない危険, 建築主の予見可能性が失われ る危険があることを指摘する。そのうえで, 建物による周辺環境悪化の程度を適切に評価した定 量基準の導入，「定性基準＋協議調整」によるまちづくりによった場合の最有効利用の実現のた めの工夫（適用対象の限定，協議期間の限定，補償制度）について述べている。

堤論説「建築規制における性能数值規定の可能性 : 集団規定の場合」は, 建物による周辺環境 悪化（外部性）に対する規制のあり方として，定量基準を前提に周辺環境悪化の程度を数值的に 計量する性能基準による規制を考察している。具体的には建物から発せられる騒音レベルの地価 減少に与える影響の計測結果から性能基準導入に当たっての課題を述べている。

関コラムは，定性基準による行政の裁量拡大は行政庁の恣意を招き平等原則や法治主義との関 係で問題をはらんでいることを指摘している。

本特集においては，定性基準導入についての論者の意見に厳しい対立が認められたが，これに より現行建築規制の問題点や定性基準の課題が明らかとなったものと思われる。 